Borneo Journal of Sciences and Technology, Volume (1), Issue (1), Pages: 03-08

DOI: https://doi.org/10.35370/bjost.2019.1.1-02

e-ISSN: 2672-7439

(C) 2018, UCTS Publisher.

Submitted: 19 September $2018 \quad$ Accepted: 21 September $2018 \quad$ Published: 31 January 2019

\title{
Community Awareness and Involvement Towards Ecotourism Activities in Ranau, Sabah
}

\author{
Andy R. Mojiol \\ Faculty of Science and Natural Resources, Universiti Malaysia Sabah, 88400 Kota Kinabalu, Sabah, \\ Malaysia
}

\begin{abstract}
The question of whether the impact of having rural communities nearby an ecotourism area being positive or negative is one of the important issues in Ranau. Cooperation between villagers and park operator on the growth of tourists' arrival is crucial and must be addressed. The aim of this study is to identify the local communities' perception at Kampung Poring and Kampung Monggis, Ranau by mean if the ecotourism activities can uplift their economic, social, physical and general impression that they experienced. In addition, the involvements of local communities in ecotourism activities in their villages were also studied. A survey and face to face interview were carried out on a sample of 146 villagers from both study areas. Data analysis using frequency, mean scores and Pearson Correlation (2-sided) was conducted. From the result, positive perception has been perceived by the villagers as a result of the improvement of ecotourism activities such as increase in employment opportunities, infrastructure facilities have been upgraded, additional revenue sources for state governments and villagers as well as increase in Small and Medium Industries (SMIs). However, the perception and level of involvement of both villages is still at the moderate level, where many other issues still need to be improved in the future such as communication skills and accommodations. In conclusion, this matter should not be taken lightly so as not to occur dissatisfaction among villagers. Therefore, the park management party should be sensitive to this situation in order to maintain the welfare of the villagers and at the same time giving satisfaction to the tourists who enjoy ecotourism activities there.
\end{abstract}

Keywords: Kampung Monggis, Kampung Poring, community perception, ecotourism activities, Ranau.

\section{INTRODUCTION}

Tourism activities were first introduced in the country since before the 70s again. However, the lack of emphasis on advertising compared with other Asian countries. Tourism development focused on areas such as the famous beach in Port Dickson and Batu Ferringhi. Tourism is one of the most important sectors in Malaysia. Visit Malaysia Year campaign in 1990 is seen as the start of interest for the public to appreciate the recreational and tourism [1]. Most tourist attractions being promoted is based on nature and ecotourism [2]. Based heritage tourism can also generate income residents from various angles. Nature tourism is defined as all types of tourism such as mass tourism, adventure tourism and so on. This tour is more focused on local culture, maintain the source attractions such as flora and fauna and also has a relationship with conservation.

Sabah is rich in natural resources and cultural heritage that attracts the attention of visitors, making tourism in Sabah a long-established industry. Industry is experiencing tremendous growth with an increasing number of tourists by 30 percent. The total area of Sabah state forest by 4.4 million hectares of land, consist of coastal forests to mountain forest of Mount Kinabalu. Forests are usually act as natural attraction not only because its flora and fauna but also mountains, rivers, waterfalls and caves [3].

The research problem of this study is the opinion of residents about the impact of tourism. The intended impact is sharing of services and infrastructure, among tourists and the villagers. It also helps to know the extent of the problem and the implications that must be addressed. Through this study, it can be seen whether the public believes that the eco-tourist activities are profitable or otherwise. The importance of this study is that in future it can provide input and a useful reference for locals, tourists, authorities and agencies involved in tourism do not think either government or private. The result of this study also allows the facility to provide better quality service that benefit the local population. Level of involvement of the people also need to recognize the extent to which understanding and public awareness of the issues around them.

Furthermore, the objective of this research, to assess the level of public perception of the ecotourism activities in Kampung Monggis and Kampung Poring through sustained impact. Lastly, the second objective 


\section{Community Awareness and Involvement Towards Ecotourism Activities in Ranau, Sabah}

is to determine the level of community involvement in Kampung Monggis and Kampung Poring towards ecotourist activities.

\section{MATERIALS AND METHODS}

\section{Study Area}

Ranau is an area which is located on the North West Coast of Sabah, Malaysia. In 2000, an estimated total population of the area is 70,649 people. Capacity for Ranau is $35,555.51 \mathrm{sq} \mathrm{km}$ and is located in between the lines of latitude $\left(5^{\circ} 30^{\prime} \mathrm{N}\right.$ and $\left.6^{\circ} 25^{\prime} \mathrm{N}\right)$ and longitude $\left(116^{\circ} 30^{\prime} \mathrm{T}\right.$ and $\left.117^{\circ} 5^{\prime} \mathrm{T}\right)$. Ranau is surrounded by seven other districts namely Tuaran, Kota Belud, Tambunan, Keningau, Pitas, Kota Marudu and Beluran. Ranau is an area known as ecotourism destination that attracts many local and foreign tourists such as Taman Kinabalu, Substations Poring Hot Spring and more. Study area that was being chosen for the research carried out are Kampung Monggis and Kampung Poring. Kampung Monggis lies between the lines of latitude $\left(6^{\circ} 02^{\prime} \mathrm{N}\right)$ and longitude $\left(116^{\circ} 42^{\prime} \mathrm{E}\right)$ and Kampung Poring is in between the lines of latitude $\left(6^{\circ} 13^{\prime} \mathrm{N}\right)$ and longitude (116 40'E). Kampung Poring, a major attraction for ecotourism that there is a Sub-station Poring Hot Springs which include Butterfly Park, Poring Orchid Conservation Center, Poring Canopy Walkway and Rafflesia Tower. Kampung Monggis is one of a substation for Mount Tombayukon which is located $45 \mathrm{~km}$ from Ranau.

\section{Sampling Method}

The research conducted for this study was stratified random sampling where the population of a large village is split by strata according to their age. The questionnaire was conducted in the period, four (4) months from January to April 2012. The study was conducted in advance in Kampung Poring in January and February because of the position of its proximity and accessibility. For Kampung Monggis, studies conducted in March and April 2012 because the place is further. In every area, the questionnaires were conducted randomly and do not focused on one area only. A total of 150 questionnaires were distributed to each location within that period but only 81 forms for Kampung Poring and 73 forms for Kampung Monggis only being answered. But to achieve the balance of the amount of the data for both locations, 73 forms for each location were being used as the data. The mean has been calculated and used to analyze each question of the respondents' perception of the villagers guided in the form of Likert scale questions. And to analyze the overall perception of respondents, mean score was been used.

Total score $=$ frequency of each scale $\mathrm{X}$ score for each scale

$$
\frac{\text { mean }(X)=\text { total score }(X)}{\text { number of respondents }(n)}
$$

Pearson correlation was used for the interpretation of the relationship between the background and the impact of the villagers. Correlation analysis technique is building a view polsa trend in pattern trend of a variable based on another variable. There are the examples of calculations for Pearson correlation formula.

$$
\begin{gathered}
r=\frac{S S X Y}{\sqrt{(S S X)(S S Y)}} \\
=\frac{\sum(x-\bar{x})(y-\bar{y})}{\sqrt{\sum(x-\bar{x})^{2} \sum(y-\bar{y})^{2}}} \\
\frac{\sum x y-\frac{\left(\sum x\right)(\Sigma y)}{n}}{\sqrt{\left[\sum x^{2}-\frac{(\Sigma x)^{2}}{n}\right]\left[\sum y^{2}-\frac{(\Sigma y)^{2}}{n}\right]}}
\end{gathered}
$$

Pearson correlation analysis was used to see the relationship between the independent variables that comprise the background of the villagers with the dependent variable which sustained the effects of the impact of the development of tourism activities. This may be the strength of the relationship between the independent variables and the dependent variable to assess the correlation (r) where the dependent variable is significant or not. Where the value of $\mathrm{p}$ above 0.05 (are not significant) or less (significantly).

\section{RESULTS AND DISCUSSION}

There were 73 sets of questionnaires completed and qualified for analysis purpose from both Kampung Monggis and Kampung Poring respectively. Data balancing is very important in analysis in order to avoid bias especially in comparing two places [4]. According to Table 1, there is a significant difference between these two villages in educational level. It can be found from the number of villagers that was able to study until university or collage level. These may be due to the problems of infrastructure, income, and lack of awareness about the importance of education and resulted Kampong Monggis only had one person (1.4\%) able to study until university or college level. Meanwhile, villagers in Kampong Poring had higher income, higher awareness toward education, and located near to the town had recorded 9 persons $(12.3 \%)$ who able to study until university level. 
Community Awareness and Involvement Towards Ecotourism Activities in Ranau, Sabah

Table 1: Demographic of villagers in educational level, income, distance between housing area and ecotourism destination.

\begin{tabular}{llcc}
\hline \multicolumn{1}{c}{ Demography } & Kampung Monggis (\%) & Kampung Poring (\%) \\
\hline Educational Level & Primary School & 21.9 & 19.2 \\
& Secondary School & 43.8 & 65.8 \\
& University/Collage & 1.4 & 12.3 \\
& Others & 32.9 & 2.7 \\
Income & RM100 & 28.8 & 12.3 \\
& RM101-RM300 & 39.7 & 23.3 \\
& RM301-RM600 & 24.7 & 30.1 \\
& RM601-RM900 & 4.1 & 16.4 \\
Distance between housing & $>$ RM901 & 2.7 & 17.8 \\
area and ecotourism & 1km-10km & 41.1 & 71.2 \\
destination & $11 \mathrm{~km}-20 \mathrm{~km}$ & 41.1 & 17.8 \\
& & 17.8 & 11.0 \\
\hline
\end{tabular}

Both villages agreed with the statement of ecotourism will increase the work opportunities. According to Zanisah [5], tourism will affect the economic level by providing more working opportunity as involvement of local communities is important. It will lead to the positive impact as they can change the quality of life by having a more secure job. There is no obvious change in Kampung Monggis (Table 2). On the other hand, Kampong Poring has made use of the existence of ecotourism destination by creating more job opportunity, for example in handicraft industry. In Kampung Poring, there were rows of retail stores operated by the villagers themselves in front of Poring Hot Spring Station.

Table 2: Perception of villagers toward ecotourism activities in aspect of economic impact.

\begin{tabular}{lcc}
\hline & Kampung Monggis (Mean) & Kampung Poring (Mean) \\
\hline Employment Opportunity & 4.36 & 4.42 \\
Economic Level & 2.36 & 3.71 \\
Income & 3.75 & 3.32 \\
\hline
\end{tabular}

Note: 1=Very Disagree, 2=Disagree, 3=Neutral, 4=Agree, 5=Very Agree

From the cultural and social aspect, perception of villagers was positive. At Kampung Monggis, majority of the villager "agree" to the statement telling tourist's attitude as they respect the local culture, thus the mean is 4.47 which is close to 5. Villagers explained that tourists do not do anything bad while staying in their home but respect each culture and taboos set. From Table 3, there are no significant difference between the mean of both village since they had same opinion in the statement. Reisinger [6] stated that the social relationship between tourist and local people depend on the similarity of their culture and tradition.

Besides, the mean value showed at Kampung Poring and Kampung Monggis were almost the same toward the statement of always had the opportunity to meet with foreign tourists due to the unique attraction at ecotourism destination respectively. For example, Poring Hot Spring Station had Rafflesia sp. and Nepenthes sp. which can be found in Gunung
Tombayukon [7]. These attractions are the main factor for tourists to pay a visit to the villages.

Both group of respondents have recorded the same mean value on the statement of sanitation improvement after existence of ecotourism destination (Table 4), because they wanted to give positive image to tourists. The highest mean value found in Kampung Poring was on the statement of improvement of infrastructure after the existence of ecotourism. Foo [8] stated that there was significant infrastructure improvement in aspect of telecommunication and transportation at Kampung Luanti Baru, Ranau after introducing System Tagal as ecotourism at the area.

While at Kampung Monggis, the mean value for the same statement was only 2.74. Through observation, this village was still lacking of infrastructure where they still have no electricity supply and paved road. Some of them explained that the location of Kampung Monggis was hard to access since 
it is a remote area. However, this condition is not a barrier to prevent tourists from visiting this place due to its uniqueness.

Table 5 showed the relationship between the aspect of perceptions which being divided into 3 main categories, namely economy, social, and infrastructure from Pearson Correlation (2-tailed) SPSS. From the table, there was no significant relationship between the distance of housing area and ecotourism destination, gender, status, and economy status after the existence of ecotourism destination.

In Table 6, there was also no significant different between the relationship of perception in aspect of religion, income, staying duration.

Table 3: Local villager's awareness toward ecotourism activities in aspect of cultural and social.

\begin{tabular}{lcc}
\hline Statement & Kampung Monggis (Mean) & Kampung Poring (Mean) \\
\hline Meet with foreign tourists & 4.44 & 4.41 \\
Medium of cultural heritages & 4.44 & 4.37 \\
Threaten of local culture & 2.19 & 2.07 \\
Introduction of foreign culture & 3.71 & 3.36 \\
Tourist's attitude & 4.47 & 4.30 \\
Affected daily life & 1.63 & 1.81 \\
\hline
\end{tabular}

Note: 1=Very Disagree, 2=Disagree, 3=Neutral, 4=Agree, 5=Very Agree

Table 4: Local villager's awareness toward ecotourism activities in aspect of physical condition.

\begin{tabular}{lcc}
\hline \multicolumn{1}{c}{ Statement } & Kampung Monggis (Mean) & Kampung Poring (Mean) \\
\hline Sanitary Level & 3.93 & 3.93 \\
Infrastructure & 2.74 & 4.30 \\
Assessing problem & 1.77 & 2.99 \\
Crime & 1.53 & 2.10 \\
Sound pollution & 1.51 & 2.62 \\
Air pollution & 1.93 & 2.64 \\
\hline
\end{tabular}

Note: 1=Very Disagree, 2=Disagree, 3=Neutral, 4=Agree, 5=Very Agree

Table 5: Relationship between the aspect of economy, gender, status and distance of housing area and ecotourism destination.

\begin{tabular}{lllcccc}
\hline \multicolumn{1}{c}{ Location } & & & Economy & Gender & Status & Distance \\
\hline Kampung & Economy & Pearson Correlation & 1 & 0.060 & -0.003 & 0.001 \\
Monggis & & (2-tailed) & & 0.614 & 0.982 & 0.994 \\
Kampung Poring & Economy & Pearson Correlation & 1 & -0.094 & 0.005 & -0.134 \\
& & (2-tailed) & & 0.431 & 0.967 & 0.257 \\
\hline
\end{tabular}

Table 6: Relationship of perception in aspect of religion, income, staying duration.

\begin{tabular}{|c|c|c|c|c|c|c|}
\hline Location & & & $\begin{array}{l}\text { Cultural } \\
\text { Medium }\end{array}$ & Religion & Income & $\begin{array}{c}\text { Staying } \\
\text { Duration }\end{array}$ \\
\hline Kampung & Cultural & Pearson Correlation & 1 & 0.154 & 0.073 & 0.195 \\
\hline Monggis & Medium & (2-tailed) & & 0.192 & 0.542 & 0.099 \\
\hline Kampung & Cultural & Pearson Correlation & 1 & -0.074 & 0.013 & 0.153 \\
\hline Poring & Medium & (2-tailed) & & 0.534 & 0.914 & 0.196 \\
\hline
\end{tabular}

Table 7 showed the relationship of the levels of infrastructure, employment opportunity, income and the distance between Kampung Monggis and ecotourism destination. The shorter the distance between Kampung Monggis and ecotourism destination, the better the infrastructure provided. In order to provide a better environment for tourists, the improvement of infrastructure is required. According to Wearing and
Neil [9], the main purpose to promote ecotourism is maximizing the benefits of tourisms, by providing more accommodation such as hotels, motels, and homestay.

According to Table 8, the involvement of local people from both villages had recorded uniformly mean value. The lowest mean value was shown in the statement of the local people had the priority in job opportunities at ecotourism destination. Both villages 


\section{Community Awareness and Involvement Towards Ecotourism Activities in Ranau, Sabah}

have the almost same mean value that is 2.12 for Kampung Monggis and 1.78 for Kampung Poring. Besides that, the highest mean value is 2.74 for Kampung Monggis and 2.78 for Kampung Poring, these two values were almost same. Villagers said that they "Never" become the driver for foreign tourists due to communication problem.

Table 7: Relationship of the levels of infrastructure, job opportunity, income and the distance between Kampung Monggis and ecotourism destination.

\begin{tabular}{lllcccc}
\hline Location & & Infrastructure & Job opportunity & Income & Distance \\
\hline Kampung & Infrastructure & Pearson & 1 & -0.105 & -0.0057 & $0.378^{* *}$ \\
Monggis & & Correlation & & 0.377 & 0.633 & 0.001 \\
& & (2-tailed) & & & & -0.187 \\
Kampung & Infrastructure & Pearson & 1 & -0.023 & 0.104 & 0.114 \\
Poring & & Correlation & & 0.846 & 0.381 & 0.114 \\
& & (2-tailed) & & & & \\
\hline
\end{tabular}

Note **Significant level of 0.01 (2-tailed)

Table 8: Involvement of local people from both village in ecotourism activities.

\begin{tabular}{lcc}
\hline Statements & Kampung Monggis & Kampung Poring \\
\hline Refer to village authorities & 2.62 & 2.16 \\
Villagers opinion & 2.64 & 2.30 \\
Decision making process & 2.56 & 2.64 \\
Work priority & 2.12 & 1.78 \\
Conservation activities & 2.66 & 2.03 \\
Conservation seminar & 2.68 & 2.53 \\
Involved in conservation seminar & 2.49 & 2.44 \\
As the driver for family and friends & 2.60 & 2.36 \\
As the driver for foreign tourists & 2.74 & 2.78 \\
Community Services & 2.59 & 2.45 \\
Involved in community services & 2.49 & 2.44 \\
\hline
\end{tabular}

\section{CONCLUSION}

Perception level of both research site has been concluded. Both sites have similar perception level on the average level. The result shows that the villagers were satisfied and agree with the development and impact in public through development of ecotourism activities in their village. This also prove that the villagers have positive perception towards the development. However, there is room of improvement from the management side. The management plan never stops growing. After a plan is being applied, it will always change as improvement is being made. The involvement of the local people is average yet they are aware of the development in their village. Not all villager participates directly to the ecotourism. Only certain amount of local people is being given job opportunity. This is being decided by the head of the villager and not by normal villager with no position. Even though most of the villagers are not involving directly to the ecotourism activity yet they can feel the change from several aspects such economy, infrastructure facilities and local culture.

\section{ACKNOWLEDGMENT}

We wish to express our sincere appreciation to the head of village of Kampung Monggis and Kampung Poring and all volunteers for their participation and support in this survey. Special thanks also go to Prof. Dr. Razak Wahab of University College of Technology Sarawak (UCTS) and Mr. Chai Chuan Jun of UMS who help in reviewing this manuscript.

\section{REFERENCES}

[1] Badaruddin, M \& Nikmatul, A. N. (2007). Perancangan Pelancongan. Kuala Lumpur. Dewan Bahasa dan Pustaka.

[2] Dowing, R. K. (2000). Ectourism in Southeast Asia: A Golden Oppurtinity for Local Communities. Book chapter in Chon, K. S. (2013). Tourism in Southeast Asia: A new direction. Routledge.

[3] Ayim, C \& Empau, E. (1996). The use of Forest in Tourism, Sabah. Proceedings of the Seminar on Nature Tourism as a Tool for Development and 
Conservation. Kundasang, Sabah on 27-29 March 1994. Institute for Development Studies Sabah.

[4] Chua, Y. P. (2006). Kaedah dan statistik penyelidikan: Asas Statistik Penyelidikan Buku 2. McGraw Hill Education. Malaysia.

[5] Zanisah, M. (2009). Kesan ekonomi pelancongan terhadap komuniti Batik di Kuala Tahan, Pahang. Junal e-Bangi: 4(1)

[6] Reisinger, Y. (1994). Tourist- host contact as part of cultural tourism. World Leisure 7 Recreation, 36 (Summer), 24-28.

[7] STB [Sabah Tourism Board]. (2008). "Visit Sabah Malaysian Borneo: Malaysia' First World Heritage Site and Surrounding Attractions" dalam Risalah.
[8] Foo, J. (2011). Sistem Tagal dalam Industri Pelancongan: Manfaat kepada komuniti. Malaysian Journal of Society \& Space. 7(1):14-25.

[9] Wearing, S \& Neil, J. (1999). Ecotourism: Impacts, Potentials and Possibilities. Butterworth Heinemann. Oxford United Kingdom. 